Pesq. Vet. Bras. 37(6):549-554, junho 2017

DOI: $10.1590 / \mathrm{S} 0100-736 \mathrm{X} 2017000600003$

\title{
Nasal swab real-time PCR is not suitable for in vivo diagnosis of bovine tuberculosis ${ }^{1}$
}

\author{
Fabiana Q. Mayer2², Emily M. dos Reis ${ }^{2}$, André Vinícius A. Bezerra ${ }^{2,3}$, Rogério 0. \\ Rodrigues ${ }^{4}$, Thais Michel ${ }^{5}$, Cristine Cerva ${ }^{2}$ and Angélica C. Bertagnolli ${ }^{3}$
}

\begin{abstract}
Mayer F.Q., Reis E.M., Bezerra A.V.A., Rodrigues R.O., Michel T., Cerva C. \& Bertagnolli A.C. 2017. Nasal swab real-time PCR is not suitable for in vivo diagnosis of bovine tuberculosis. Pesquisa Veterinária Brasileira 37(6):549-554. Laboratório de Biologia Molecular, Instituto de Pesquisas Veterinárias Desidério Finamor, Fundação Estadual de Pesquisa Agropecuária, Estrada Municipal do Conde 6000, Eldorado do Sul, RS 92990-000, Brazil. E-mail: bimmayer@gmail.com

Bovine tuberculosis (bTB) is a zoonosis causing economic losses and public health risks in many countries. The disease diagnosis in live animals is performed by intradermal tuberculin test, which is based on delayed hypersensitivity reactions. As tuberculosis has complex immune response, this test has limitations in sensitivity and specificity. This study sought to test an alternative approach for in vivo diagnosis of bovine tuberculosis, based on real-time polymerase chain reaction (PCR). DNA samples, extracted from nasal swabs of live cows, were used for SYBR ${ }^{\circledR}$ Green real-time PCR, which is able to differentiate between Mycobacterium tuberculosis and Mycobacterium avium complexes. Statistical analysis was performed to compare the results of tuberculin test, the in vivo gold standard bTB diagnosis method, with realtime PCR, thereby determining the specificity and sensitivity of molecular method. Cervical comparative test (CCT) was performed in 238 animals, of which 193 had suitable DNA from nasal swabs for molecular analysis, as indicated by amplification of glyceraldehyde-3-phosphate dehydrogenase (GAPDH) gene, and were included in the study. In total, 25 (10.5\%) of the animals were CCT reactive, of which none was positive in the molecular test. Of the 168 CCT negative animals, four were positive for $M$. tuberculosis complex at real time PCR from nasal swabs. The comparison of these results generated values of sensitivity and specificity of $0 \%$ and $97.6 \%$, respectively; moreover, low coefficients of agreement and correlation $(-0.029$ and -0.049 , respectively) between the results obtained with both tests were also observed. This study showed that real-time PCR from nasal swabs is not suitable for in vivo diagnosis of bovine tuberculosis; thus tuberculin skin test is still the best option for this purpose.
\end{abstract}

INDEX TERMS: Nasal swab real-time PCR, bovine tuberculosis, tuberculin test, molecular diagnosis, Mycobacterium tuberculosis complex, Mycobacterium avium complex, Mycobacterium bovis.

\footnotetext{
${ }^{1}$ Received on June 12, 2015.

Accepted for publication on November 2016.

${ }^{2}$ Laboratório de Biologia Molecular, Instituto de Pesquisas Veterinárias Desidério Finamor, Fundação Estadual de Pesquisa Agropecuária, Estrada Municipal do Conde 6000, Eldorado do Sul, RS 92990-000, Brazil. *Corresponding author: bimmayer@gmail.com

${ }^{3}$ Laboratório de Histopatologia, Instituto de Pesquisas Veterinárias Desidério Finamor, Fundação Estadual de Pesquisa Agropecuária, Estrada Municipal do Conde 6000, Eldorado do Sul, RS 92990-000, Brazil.

${ }^{4}$ Laboratório de Leptospirose, Instituto de Pesquisas Veterinárias Desidério Finamor, Fundação Estadual de Pesquisa Agropecuária, Estrada Municipal do Conde 6000, Eldorado do Sul, RS 92990-000, Brazil.

${ }^{5}$ Laboratório de Parasitologia, Instituto de Pesquisas Veterinárias Desidério Finamor, Fundação Estadual de Pesquisa Agropecuária, Estrada Municipal do Conde 6000, Eldorado do Sul, RS 92990-000, Brazil.
}

RESUMO.- [A PCR em tempo real de swab nasal não é adequada para o diagnóstico in vivo de tuberculose bovina.] A tuberculose bovina (bTB) é uma zoonose que causa perdas econômicas e riscos à saúde pública em muitos países. O diagnóstico da doença em animais vivos é realizado pelo teste intradérmico da tuberculina, que é baseado em reações de hipersensibilidade tardia. Como a tuberculose tem resposta imunológica complexa, este teste tem limitações em termos de sensibilidade e especificidade. Este estudo procurou desenvolver uma abordagem alternativa para o diagnóstico in vivo da tuberculose bovina, com base na reação em cadeia da polimerase (PCR) em tempo real. As amostras de DNA, extraídas de suabes nasais de vacas 
vivas, foram usadas para PCR em tempo real com $\mathrm{SYBR}^{\circledR}$ Green, capaz de diferenciar os complexos Mycobacterium tuberculosis e Mycobacterium avium. A análise estatística foi realizada para comparar os resultados de teste de tuberculina, padrão ouro para o diagnóstico in vivo da bTB, com PCR em tempo real, determinando-se assim a especificidade e sensibilidade do método molecular. 0 teste cervical comparativo (TCC) foi realizado em 238 animais, dos quais 193 tiveram DNA dos suabes nasais adequados para análise molecular, como indicado pela amplificação do gene gliceraldeído-3-fosfato-desidrogenase (GAPDH), e foram incluídos no estudo. No total, $25(10,5 \%)$ animais foram reativos no TCC, dos quais nenhum foi positivo no teste molecular. Dos 168 animais negativos no TCC, quatro foram positivos para o complexo M. tuberculosis na PCR em tempo real a partir dos suabes nasais. A comparação destes resultados gerou valores de sensibilidade e especificidade de $0 \%$ e 97,6\%, respectivamente; além disso, baixos coeficientes de concordância e correlação $(-0,029$ e - $-0,049$, respectivamente) entre os resultados obtidos com ambos os testes também foram observados. Este estudo mostrou que a PCR em tempo real a partir de suabes nasais não é adequada para o diagnóstico in vivo da tuberculose bovina; portanto, o teste da tuberculina ainda é a melhor opção para este fim.

TERMOS DE INDEXAÇÃO: PCR em tempo real, swab nasal, tuberculose bovina, teste da tuberculina, diagnóstico molecular, complexo Mycobacterium tuberculosis, complexo Mycobacterium avium, Mycobacterium bovis.

\section{INTRODUCTION}

Bovine tuberculosis (bTB) is a globally distributed zoonosis caused mostly by Mycobacterium bovis (Michel et al. 2010). In addition to public health implications, bTB is responsible for economic losses in agriculture, even in developed countries (Karolemeas et al. 2012). In countries where bTB prevalence is high, the main way of bTB control and eradication is based on diagnostic and slaughter of infected animals (Brasil 2006); thus, efficient in vivo diagnosis becomes necessary.

In vivo bTB diagnoses is made mainly by the intradermal tuberculin test, which involves inoculation of purified protein from Mycobacterium bovis (PPD-B) and measurement of local hypersensitivity reaction after $72 \mathrm{~h}$. When applied in combination with slaughter surveillance and herd movement control, this test has been efficient in bTB control and eradication in some countries (Karolemeas et al. 2012). Despite this, in several situations the tuberculin test has limitations due to lack of sensitivity and specificity, even when applied as a comparative cervical test (CCT) using a purified protein derivative of Mycobacterium avium (PPD-A) to avoid false positive results (Zarden et al. 2013). This limited efficiency may contribute to the incidence maintenance of bTB in some countries.

The problems associated with tuberculin test led researchers to seek for new methods to diagnose bTB in livestock. Among them, interferon gamma (IFN- $\gamma$ ) assay is performed in vitro to detect specific cell-mediated immune responses (Wood et al. 1990). This is an ELISA test that detects IFN- $\gamma$ released from in vitro stimulated Tlymphocytes. It also evaluates the difference between values achieved with PPD-A and PPD-B stimulation, being analogous to CCT (Schiller et al. 2010). IFN- $\gamma$ assay has increased sensitivity, but has limitations such as reduced specificity, high logistical demands, high costs, and difficulties in the standardization of purified proteins (Schiller et al. 2010). Another emerging strategy is bTB antibody detection, which had some difficulties since immunological response to Mycobacterium bovis, especially in early stages, is mainly cellular-mediated. Preliminary studies have indicated the potential for these tests, but large-scale field trials at different sites may be required to define serological test accuracy (Schiller et al. 2010).

Among the novel approaches to $M$. bovis detection, PCRbased methods are efficient to differentiate among Mycobacterium species and are being widely studied as an alternative to postmortem diagnosis. As bTB pathogenesis studies suggest that the main route of the disease transmission is via respiratory system, Mycobacterium spp. investigation in nasal swabs can be an efficient way to detect the disease (Cassidy 2006). In this sense, the aim of the present study was to evaluate the effectiveness of a molecular test, using DNA from bovine nasal swabs, for in vivo bTB diagnosis. To reach this objective, the results of a real time PCR to detect Mycobacterium tuberculosis complex bacteria were compared to the tuberculin test, the in vivo gold standard test.

\section{MATERIALS AND METHODS}

This study was approved by the Ethics Committee on Animal Use (CEUA-IPVDF) under protocol 01/2012. The study population was comprised by 238 bovines which were tested by intradermal CCT test between July and August 2012. These animals derived from 27 dairy and mixed herds of Rio Grande do Sul (RS), the Brazilian southern state (Table 1 ).

Nasal swabs were collected by vigorous swabbing inside the nostrils ( 5 to $10 \mathrm{~cm}$ deep) of the animal and immediately kept on 300 $\mu \mathrm{L}$ of $1 \mathrm{x}$ Tris-EDTA (TE) buffer at $-20^{\circ} \mathrm{C}$ until analysis. The samples were collected immediately prior to tuberculin test.

All the animals were subjected to CCT tests conducted according to recommendations by Brazilian Department of Agriculture (Brasil 2006). The avian and bovine PPD tuberculin were inoculated intradermal in the middle third of the neck of each animal The avian tuberculin PPD was inoculated cranially and the bovine tuberculin PPD was inoculated caudally (12 cm apart) at a dose of $0.1 \mathrm{ml}$ of each PPD. The skin thickness was measured with cutimeter before the inoculations and 72 hours later. Differences in the skin thickness between pre-injection and post-injection measurements were calculated to classify the animal as positive, suspicious, or negative. An animal was classified as PPD-positive if the skin thickness at the inoculation site for the PPD was at least $4 \mathrm{~mm}$ greater than the skin thickness at the inoculation site for avian PPD. If the difference on skin thicknesses at the inoculation sites for the bovine and avian PPD was between 2.0 and $3.9 \mathrm{~mm}$, the animal was considered inconclusive. In the evaluated population, the farmers agreed in slaughter animals with inconclusive tests. All tuberculin tests were conducted by the same veterinarian. Animals with positive reactions to CCT were slaughtered under official sanitary inspection, also following plan's instructions.

At slaughter, bovine organs were inspected in search of granulomatous lesions. Lungs and lymph nodes from all animals, even those without visible lesions, were collected and brought to the 
laboratory for a carefully inspection. This inspection consisted in a systematic evaluation, through visual and tactile examination with subsequent deep longitudinal incision in all collected organs. Nodular lesions, with purulent, caseous or calcificated areas were considered as suggestive of bTB.

All the collected tissues were submitted to decontamination by Petroff's method and Mycobacterium spp. culture in Stonebrink and Lowenstein Jensen medium according to World Health Organization (WHO). The isolates were subjected to Zihel-Neelsen staining to confirm the presence of acid-fast bacilli.

For molecular analysis, DNA extraction protocol was adapted from Zumárraga et al. (2005). Briefly, the swab in TE $1 \mathrm{X}$ was incubated at $80{ }^{\circ} \mathrm{C}$ for 30 minutes for Mycobacterium spp. inactivation. After removing the swab from the tube, the samples were incubated at $37^{\circ} \mathrm{C}$ for 30 minutes with $20 \mathrm{mg} / \mathrm{mL}$ of Lysozyme (Sigma-Aldrich, St Louis, MO, USA). Samples were incubated at $65^{\circ} \mathrm{C}$ for 10 minutes after addition of $100 \mu \mathrm{L} 10 \%$ SDS and $25 \mathrm{mg} /$ $\mathrm{mL}$ of Proteinase K (Ambion, Foster City, CA, USA). Then, $100 \mu \mathrm{L}$ of $0.27 \mathrm{M}$ N-cetyl-N,N,N,trimethlyl ammonium bromide/0.7 M $\mathrm{NaCl}$ and $140 \mu \mathrm{L}$ of $3.6 \mathrm{M} \mathrm{NaCl}$ were added. Samples were mixed vigorously and incubated at $65^{\circ} \mathrm{C}$ for 10 minutes. After this step, one volume of chloroform/isoamyl alcohol (24:1) was added, the samples were homogenized and centrifuged at $14,000 \mathrm{rpm}$ at $4^{\circ} \mathrm{C}$ for 5 minutes. DNA precipitation was performed by adding 0.6 volume of isopropanol. Samples were centrifuged at $14,000 \mathrm{rpm}$ at $4^{\circ} \mathrm{C}$ for 10 minutes and washed with $70 \%$ ethanol. DNA was eluted in $30 \mu \mathrm{L}$ of $1 \mathrm{x}$ TE and quantified at Nanodrop 1000 (Thermo Fisher Scientific, Wilmington, DE, USA). A conventional PCR for Glyceraldehyde-3-phosphate dehydrogenase (GAPDH) gene was performed as described by Cerva et al. (2014) to confirm the absence of inhibitors in DNA; then, the suitable samples were subjected to a SYBR ${ }^{\circledR}$ Green (Invitrogen, Carlsbad, CA, USA) real-time PCR able to differentiate, with the same primer pair, between Mycobacterium tuberculosis and Mycobacterium avium complexes by the melting temperature $\left(90.1^{\circ} \mathrm{C}\right.$ and $92.7^{\circ} \mathrm{C}$, respectively - Supplementary Fig.1) (Jaime et al. 2010, Bezerra et al. 2015). The reactions were performed in duplicate at StepOne thermocycler (Life Technologies, USA) with $6.25 \mu \mathrm{L}$ of Platinum ${ }^{\circledR}$ SYBR $^{\circledR}$ Green qPCR SuperMix-UDG (Applied Biosystems, USA), $0.2 \mu \mathrm{M}$ of each primer, $0.5 \mu \mathrm{L}$ of ROX and ultra-pure water to a final volume of $12.5 \mu \mathrm{L}$. The temperature cycles were hold at $50^{\circ} \mathrm{C}$ for 2 minutes, hold at $95^{\circ} \mathrm{C}$ for 2 minutes, followed by 40 cycles of $95^{\circ} \mathrm{C}$ for $15 \mathrm{~s}$ and $60^{\circ} \mathrm{C}$ for $1 \mathrm{~min}$. Melting curve was performed with a gradual

Table 1. Characteristics of animals included in study

\begin{tabular}{lcc}
\hline Variable & & Frequency $\mathrm{n}(\%)$ \\
\hline Sex & Female & $175(91.14)$ \\
& Male & $17(8.86)$ \\
Age $(\mathrm{x}$, years) & $\mathrm{x}<1$ & $39(20.32)$ \\
& $1 \geq \mathrm{x}<2$ & $27(4.06)$ \\
Breed & $\mathrm{x} \geq 2$ & $126(65.62)$ \\
& Jersey & $46(23.95)$ \\
& Holand & $72(37.5)$ \\
& Mixed & $74(38.55)$
\end{tabular}

increase of $0.3^{\circ} \mathrm{C}$ from $60^{\circ} \mathrm{C}$ to $95^{\circ} \mathrm{C}$ (Mayer et al. 2012). Controls were added in each run; bacterial DNA from both complexes was used as amplification control and ultra-pure water as non-template control. Real-time PCR analytical sensitivity was 1,000 molecules of Mycobacterium DNA with $90.4 \%$ efficiency $\left(r^{2}=0.996\right)$, according to data previously published by our group (Mayer et al. 2012). All the primers used in this study are presented in Table 2.

Statistical analysis was performed using Stata software 10.1 (Stata Corporation, College Station, Texas, USA). The sensitivity, specificity, positive and negative predictive values between real time PCR from nasal swabs and CCT were calculated with the CCT criteria for as the gold standard for in vivo bTB. The agreement between the real time PCR from nasal swabs and CCT was assessed by the Kappa coefficient (Landis \& Kock 1977). The correlation between the tests was analyzed by determining Pearson coefficient. Statistical significance was considered with $\mathrm{p}<0.05$.

\section{RESULTS}

Out of 238 tested animals, 13 were positive and 12 were inconclusive on CCT test. Inconclusive results were considered as positive, thus all 25 animals were sent to slaughter under official inspection. This represents $10.5 \%$ of bTB frequency of evaluated animals. Tissue samples were obtained from 23 of 25 CCT positive animals. Of collected samples, 12 (52.2\%) had visible lesions consistent with tuberculosis and 4 (17.4\%) had isolated Mycobacterium spp. (Table 3). Of the isolates, 3 were retrieved from tissues with visible lesions and one of them from a tissue with no visible lesion (Table 3).

DNA was extracted from 238 swabs samples; however, only 193 were positive for GAPDH amplification, being included in the study. From these samples, 25 were positive on CCT test (Tables 2 and 3 ) and of these none was positive to Mycobacterium tuberculosis real-time PCR; moreover, 4 animals, which were negative at CCT, resulted positive for M. tuberculosis complex with the molecular method (with CTs of 31.9, 31.7, 32.0 and 29.0). Thus, the sensitivity (true positive within the positive results) and specificity (true negatives within the negative results) of the proposed molecular method, when compared to CCT were $0 \%$ and $97.6 \%$, respectively. Positive predictive value (PPV) and negative predictive value (NPV) were $0 \%$ and $86.77 \%$, respectively (Table 4). Low agreement coefficient (Kappa, $-0.029, p=0.499$ ) and correlation coefficient (Pearson, $-0.049, \mathrm{p}=0.502$ ) were observed.

Regarding M. avium complex, 4 samples were positive in this test, of which one was inconclusive at CCT test (sample number 1, Table 3). The other three samples were negative at CCT. There was no correlation between the positivity to M. avium complex at the real-time PCR and the reactivity to PPD-A (data not shown).

Table 2. Primers used in the present study

\begin{tabular}{lccc}
\hline Target & Primers $\left(5^{\prime}-3^{\prime}\right)$ & Amplicon size $(\mathrm{bp})$ & Reference \\
\hline GAPDH & Fwd: CCCATCACCATCTTCCAGG & 550 & Mayer et al. \\
& Rev: CATATTTGGCAGCTTTCTCC & & 2012 \\
M. bovis & Fwd: BoF - CCTTCCGCACACCGTTCAG & 436 & Mayer et al. \\
& Rev: BoR - CATCAGTGGGGACGCTACTACG & & 2012 \\
Myc & Fwd: Myc1 - GAGTAGGTCATGGCTCCTCC & 178 (MTC) & Gómez-Laguna et al. \\
& Rev: Myc3 - CATGCACCGAATTAGAACGT & 257 (MAC) & 2010
\end{tabular}




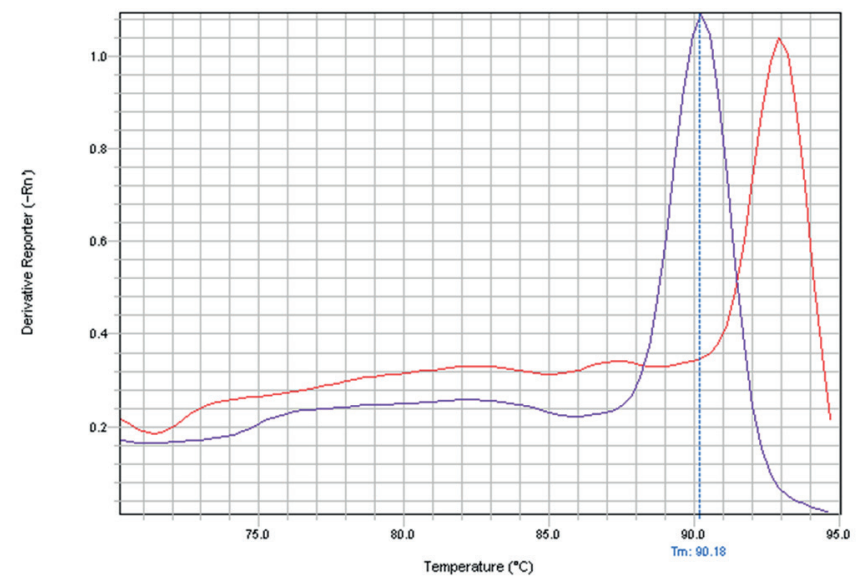

Supplementary Fig.1. Melt curve of qPCR reaction showing the Mycobacterium tuberculosis (purple line) and Mycobacterium avium (red line) melting temperatures.

Table 3. Tissue evaluation of animals slaughtered under official inspection. The nasal swabs of all the animals listed in this table were negative on real time PCR for Mycobacterium tuberculosis and M. avium complexes

\begin{tabular}{ccccc}
\hline Animal & CCT & Tissue & Visible lesion & Culture \\
\hline $1^{*}$ & Inconclusive & Lymph node & Yes & Negative \\
2 & Inconclusive & Lungs & No & Negative \\
3 & Positive & Lymph node and lungs & Yes & Negative \\
4 & Positive & Lymph node and lungs & No & Negative \\
5 & Positive & Lymph node and lungs & No & Negative \\
6 & Positive & Lymph node & Yes & Negative \\
7 & Positive & Lymph node & Yes & Positive \\
8 & Positive & Lymph node and lungs & Yes & Negative \\
9 & Positive & Liver & Yes & Negative \\
10 & Positive & Lungs & Yes & Negative \\
11 & Positive & Lungs & No & Negative \\
12 & Positive & Lymph node & Yes & Positive \\
13 & Positive & Lungs & No & Negative \\
14 & Positive & Lymph node & Yes & Negative \\
15 & Inconclusive & Lymph node & No & Negative \\
16 & Positive & Not tested & Not tested & Not tested \\
17 & Inconclusive & Lymph node & No & Negative \\
18 & Positive & Lungs & Yes & Negative \\
19 & Positive & Lungs & Yes & Positive \\
20 & Positive & Lymph node and lungs & No & Negative \\
21 & Positive & Lungs & No & Positive \\
22 & Inconclusive & Liver & No & Negative \\
23 & Positive & Not tested & Not tested & Not tested \\
24 & Positive & Lungs & Yes & Negative \\
25 & Inconclusive & Lungs & No & Negative
\end{tabular}

*Sample positive for Mycobacterium avium complex at real-time PCR.

\section{DISCUSSION}

In vivo tests for bTB approved by Organization of International Epizootics (OIE) include intradermal tuberculin skin test as prescribed test and IFN- $\gamma$ ELISA assay as alternative test (OIE 2004). These tests can be applied together to increase sensitivity and specificity. Nevertheless, false results are still obtained, which is a problem to overcome by control and eradication programs. False negative results have been reported due to early infection, immunosuppression and advanced or generalized bTB (Kehrli et al. 1989, Monaghan et al. 1994, Charleston et al. 2001, Pollock \& Neill
Table 4. Comparison between the results obtained with tuberculin and real-time PCR of nasal swabs (Sensitivity: 0\%; specificity: 97.6\%; PPV: 0\%; NPV: 86.77\%)

\begin{tabular}{lccc}
\hline M. tuberculosis complex PCR & \multicolumn{3}{c}{ CCT tuberculin skin test } \\
\cline { 2 - 4 } & Positive & Negative & Total \\
\hline Positive & 0 & 4 & 4 \\
Negative & 25 & 164 & 189 \\
Total & 25 & 168 & 193
\end{tabular}

2002). Factors related to the storage, manufacturing and method of administration of tuberculin might also cause false negative results (Monaghan et al. 1994). Thus, the development of an alternative in vivo test is important for a more appropriate disease control and would facilitate the study of tuberculosis in wild animals, that also can be reservoirs of this disease.

Based on that, the present study evaluated if PCR from nasal swabs for Mycobacterium spp. detection is effective for in vivo bTB diagnosis. The advantages of using nasal swabs to bTB diagnosis would be great, since they can be easier collected from live animals, and could be applied to study Mycobacterium spp. in wildlife species, for which slaughter is not allowed and tuberculin test is not optimized. However, the results indicated that this technique was not effective when compared to tuberculin skin test, with low agreement values and lower sensitivity. From all animals tested positive for CCT, none was positive for M. tuberculosis complex with nasal swabs real-time PCR (Table 4). On the other hand, 4 animals that were negative for CCT, tested positive for M. tuberculosis complex with the molecular method. It is possible that these animals were in advanced stage of disease, being anergic to tuberculin skin test and with higher bacterial loads on their nasal secretion. If this this is case, it is possible that nasal swab real time PCR could be useful to detect anergic animals, which is one of tuberculin skin test limitations; however, as CCT was negative, these animals were not slaughtered, which prevented bTB confirmation. Thus, more studies on this subject should be carried out to confirm this hypothesis.

Despite the present study has shown inefficiency of PCR from nasal swabs to diagnose bTB in vivo, previous studies showed different results and interpretations. Figueiredo et al. (2010) identified 5.9\% of positive PCR results in nasal swabs among 34 cattle positive in intradermal tuberculin test. Even with low sensitivity, the authors suggested that this method can be used as ancillary for surveillance of bovine tuberculosis in herds or as confirmatory for animals with inconclusive tuberculin results. Their conclusion is based on the fact that swab PCR had higher positivity frequency than swab culture, which was $0 \%$. In the present study, the swab culture was not performed, since the goal was to evaluate the efficiency of real time PCR as an alternative to in vivo bTB diagnose; then the comparison was made only to the tuberculin test, which is the gold standard for this purpose. Moreover, the swab culture would have the limitations related to Mycobacterium spp. handling as biosafety issues and time to obtaining the result.

Vitale et al. (1998) showed low sensitivity and high specificity of nasal swab PCR; however, the study compared 
the nasal swab PCR with results of tissue PCR; the authors suggested the association of both techniques in samples from the same subjects. Another study found 100\% of agreement between nasal swabs PCR and tuberculin results, with 3 of 210 evaluated animals resulting positive in both tests (Solmaz et al. 2009). The difference on the results from that study to ours can be related to the DNA extraction method, which was made by commercial kit in the first study and in-house in the present; however, as we could detect Mycobacterium spp. DNA in a few samples, the ability of the extraction method was proven to be effective. Moreover, we used an internal control (GAPDH) to be sure of the success of DNA extraction. Thus, other possibilities to the different observed outcomes can be pointed, such as the disease stage of the tested animals and the routes of infection by which they were infected.

Several explanations can be pointed for the failure to detect Mycobacterium spp. in nasal swabs of tuberculous cattle by real-time PCR. Usually, when applied in bacterial cultures the efficiency of PCR is excellent; however, in samples in which there is the presence of the matrix (such as tissues, mucous, etc.), the efficiency will be dependent on the bacterial loads in the sample. This can be one possible explanation to the observed results, since bacterial loads lower than 1000 (detection limit of the PCR used in the present study) may be secreted by nasal fluids. This is what seems to happen in field situations, as Palmer et al. (2002) has shown that experimental infections with aerosols are more similar to natural infection with lower bacilli doses. Following this rationality, Neill et al. (1991), through a mathematical model, suggested that infection could be established following inhalation of a single bacillus. In this sense, the results of the present study are in accordance with other authors have been discussed, who pointed out that it is unrealistic to consider PCR as alternative to immunological tools for tuberculosis routine diagnosis in live cattle, since it requires samples with high bacillary burdens (De la Rua-Domenech et al. 2006). In humans, sputum has been used for tuberculosis diagnosis and studies show good sensitivities values. A recent study showed sensitivity of $90.3 \%$ of a real-time (RT)-PCR targeting mpt64 gene. Sputum seems to be more adequate for diagnosis purposes, since it is obtained from the inferior respiratory tract, and therefore it is more likely to have higher bacillary loads than nasal secretions. In cattle, the evaluation of sputum could be considered, although there would be difficulties related to the collection, and it does not solve the detection problem in cases of non-pulmonary or not active tuberculosis.

The number of excreted bacilli may be influenced by disease stage (Pollock et al. 2006). Although there are studies suggesting that animals with tuberculosis can excrete bacilli from the onset of disease, the shedding rate may be influenced by disease severity (Stamp 1944). Animals experimentally infected with higher doses of bacilli had higher severity on pathological lesions and enhanced frequency of shedding (McCorry et al. 2005). Moreover, although cattle are most likely to be infected with $M$. bovis through inhalation of aerosolized droplets, oral routes are also responsible for infections (Neill et al. 1994, Palmer et al. 2004). Some authors state that oral route may be responsible for lesions preferentially on mesenteric lymph nodes (Biet et al. 2005, Riet-Correa \& Garcia 2007). However, there is evidence that oral route lead to lesions limited to the lung, pulmonary and cranial lymph nodes (Palmer et al. 2004). The fact is that animals without lung or pulmonary lymph nodes lesions are not able to spread $M$. bovis through respiratory routes. Studies have suggested that only $9 \%$ to $19 \%$ of infected cattle shed M. bovis in nasal or tracheal secretions (Palmer \& Waters 2006). In the present study, 12 animals (52.2\%) were positive for CCT and had lesions at postmortem examination, however only 4 (16\%) had Mycobacterium spp. isolation. When considering the affected organ, only 6 animals had lung lesions compatible with tuberculosis and in just 2 of them was possible to isolate Mycobacterium spp. Nevertheless, as none had positive results on nasal swab real-time PCR, we can assume that intradermal tuberculin skin test is more sensitive than nasal swabs PCR for in vivo bovine tuberculosis diagnosis. It is important to point that more studies should be carried out to evaluate the effectiveness of real time PCR to detect advanced bTB stages, in which the tuberculin results false negative and bacterial loads may be higher in animal secretions.

Acknowledgements.- Emily Marques dos Reis was recipient of Financiadora de Estudos e Projetos (FINEP)/ Conselho Nacional de Desenvolvimento Científico e Tecnológico (CNPq) scholarship and André Vinícius Andrade Bezerra was recipient of Fundação de Amparo à Pesquisa do Estado do Rio Grande do Sul (FAPERGS) scholarship. This work was financially supported by CNPq with grant number 478660/2013-8. The sponsor had no role on study design; in the collection, analysis and interpretation of data; in the writing of the manuscript; and in the decision to submit the article for publication.

\section{REFERENCES}

Bezerra A.V., Dos Reis E.M., Rodrigues R.O., Cenci A., Cerva C. \& Mayer F.Q. 2015. Detection of detection of Mycobacterium tuberculosis and Mycobacterium avium Complexes by Real-Time PCR in bovine milk from Brazilian dairy farms. J. Food Prot. 78:1037-1042.

Biet F., Boschiroli M.L., Thorel M.F. \& Guilloteau L.A. 2005. Zoonotic aspects of Mycobacterium bovis and Mycobacterium avium-intracellulare complex (MAC). Vet. Res. 36:411-436.

Brasil 2006. Programa Nacional de Controle e Erradicação da Brucelose e da Tuberculose Animal (PNCEBT)/organizers, Vera Cecilia Ferreira de Figueiredo, José Ricardo Lôbo, Vitor Salvador Picão Gonçalves. Ministério da Agricultura, Pecuária e Abastecimento, MAPA/SDA/DSA, Brasília, DF. 188 p.

Cassidy J.P. 2006. The pathogenesis and pathology of bovine tuberculosis with insights from studies of tuberculosis in humans and laboratory animal models. Vet. Microbiol. 112:151-161.

Cerva C., Bremm C., Dos Reis E.M., Bezerra A.V., Loiko M.R., Cruz C.E., Cenci A. \& Mayer F.Q. 2014. Food safety in raw milk production: Risk factors associated to bacterial DNA contamination. Trop. Anim. Health Prod. 46:877-882.

Charleston B., Hope J.C., Carr B.V. \& Howard C.J. 2001. Masking of two in vitro immunological assays for Mycobacterium bovis (BCG) in calves acutely infected with non-cytopathic bovine viral diarrhoea virus. Vet. Rec. 149:481-484.

Figueiredo E.E.S., Carvalho R.C.T., Silvestre F.G., Lilenbaum W., Fonseca L.S., Silva J.T. \& Paschoalin V.M.F. 2010. Detection of Mycobacterium bovis DNA in nasal swabs from tuberculous cattle by a multiplex PCR. Braz. J. Microbiol. 41:386-390. 
Gómez-Laguna J., Carrasco L., Ramis G., Quereda J.J., Gómez S. \& Pallarés F.J. 2010. Use of Real-Time and Classic Polymerase Chain Reaction Assays for the diagnosis of porcine tuberculosis in formalin-fixed, paraffin-embedded tissues. J. Vet. Diagn. Investig. 22:123-127.

Karolemeas K., la Rua-Domenech R., Cooper R., Goodchild A.V., Clifton-Hadley R.S., Conlan A.J., Mitchell A.P., Hewinson R.G., Donnelly C.A., Wood J.L. \& McKinley T.J. 2012. Estimation of the relative sensitivity of the comparative tuberculin skin test in tuberculous cattle herds subjected to depopulation. PLoS One 7:e43217.

Kehrli M.E., Nonnecke B.J. \& Roth J.A. 1989. Alterations in bovine lymphocyte function during the periparturient period. Am. J. Vet. Res. 50: 215-220.

de la Rua-Domenech R., Goodchild A.T., Vordermeier H.M., Hewinson R.G., Christiansen K.H. \& Clifton-Hadley R.S. 2006. Ante mortem diagnosis of tuberculosis in cattle: a review of the tuberculin tests, $\gamma$-interferon assay and other ancillary diagnostic techniques. Res. Vet. Sci. 81:190-210.

Mayer F.Q., Cerva C., Driemeier D., Cruz C.E., Loiko M.R., Coppola M.M., Cibulski S. \& Bertagnolli A.C. 2012. Mycobacterium bovis infection in a collared peccary (Tayassu tajacu): insights on tuberculosis wild reservoirs. Vet. Microbiol. 160:549-551.

McCorry T., Whelan A.O., Welsh M.D., McNair J., Walton E., Bryson D.G., Hewinson R.G., Vordermeier H.M. \& Pollock J.M. 2005. Shedding of Mycobacterium bovis in the nasal mucus of cattle infected experimentally with tuberculosis by the intranasal and intratracheal routes. Vet. Rec. 157:613-618.

Michel A.L., Müller B. \& Van Helden P.D. 2010. Mycobacterium bovis at the animal-human interface: a problem, or not? Vet. Microbiol. 140:371-381.

Monaghan M.L., Doherty M.L., Collins J.D., Kazda J.F. \& Quinn P.J. 1994. The tuberculin test. Vet. Microbiol. 40:111-124.

Neill S.D., O’Brien J.J. \& Hanna J. 1991. A mathematical model for Mycobacterium bovis excretion from tuberculous cattle. Vet. Microbiol. 28:103109.

Neill S.D., Pollock J.M., Bryson D.B. \& Hanna J. 1994. Pathogenesis of Mycobacterium bovis infection in cattle. Vet. Microbiol. 40:41-52.

OIE 2004. World Organization for Animal Health. Manual of Diagnostic Tests and Vaccines for Terrestrial Animals. 5th ed. Web version, Vol.1 and 2, Paris.

Palmer M.V., Waters W.R. \& Whipple D.L. 2002. Aerosol delivery of virulent Mycobacterium bovis to cattle. Tuberculosis 82:275-282.

Palmer M.V. \& Waters W.R. 2006. Advances in bovine tuberculosis diagno- sis and pathogenesis: what policy makers need to know. Vet. Microbiol. 112:181-190.

Palmer M.V., Waters W.R., Whipple D.L., Slaughter R.E. \& Jones S.L. 2004. Evaluation of an in vitro blood-based assay to detect production of interferon-gamma by Mycobacterium bovis-infected white-tailed deer (Odocoileus virginianus). J. Vet. Diagn. Invest. 16:17-21.

Pollock J.M. \& Neill S.D. 2002. Mycobacterium bovis infection and tuberculosis in cattle. Vet. J. 163:115-127.

Pollock J.M., Rodgers J.D., Welsh M.D. \& McNair J. 2006. Pathogenesis of bovine tuberculosis: The role of experimental models of infection. Vet. Microbiol. 112:141-150.

Riet-Correa F. \& Garcia M. 2007. Tuberculose, p.432-442. In: Riet-Correa F., Schild A., Méndez M. \& Lemos R. (Eds), Doenças Ruminantes e Equinos. Pallotti, Santa Maria.

Schiller I., Oesch B., Vordermeier H.M., Palmer M.V., Harris B.N., Orloski K.A., Buddle B.M., Thacker T.C., Lyashchenko K.P. \& Waters W.R. 2010. Bovine tuberculosis: a review of current and emerging diagnostic techniques in view of their relevance for disease control and eradication. Transbound. Emerg. Dis. 57:205-220.

Solmaz H., İlhan Z., Aksakal A., Gülhan T. \& Ekin İ.H. 2009. Detection of bovine tuberculosis by tuberculin test and polymerase chain reaction in Van, Turkey. Turk. J. Vet. Anim. Sci 33:229-233.

Stamp J.T. 1944. A review of the pathogenesis and pathology of bovine tuberculosis with special reference to practical problems. Vet. Rec 56:443446.

Vitale F., Capra G., Maxia L., Reale S., Zooprofilattico I. \& Della S. 1998. Detection of Mycobacterium tuberculosis complex in cattle by PCR using milk, lymph node aspirates, and nasal swabs. J. Clin. Microbiol. 36:10501055.

Wood P.R., Corner L.A. \& Plackett P. 1990. Development of a simple, rapid in vitro cellular assay for bovine tuberculosis based on the production of gamma interferon. Res. Vet. Sci. 49:46-49.

Zarden C.F.O., Marassi C.D., Carvalho A.C., Figueiredo E.E.S. \& Lilenbaum W. 2013. Bacteriological and molecular detection of Mycobacterium bovis in cattle with inconclusive results to intradermal tuberculin tests. Epidemiol. Infect. 141:1390-1393.

Zumárraga M.J., Meikle V., Bernardelli A., Abdala A., Tarabla H., Romano M.I. \& Cataldi A. 2005. Use of Touch-Down Polymerase Chain Reaction to enhance the sensitivity of Mycobacterium Bovis detection. J. Vet. Diagn. Invest. 17:232-238. 